\title{
KAJIAN STRATEGI PENGEMBANGAN USAHA MIKRO KECIL DAN MENENGAH (UMKM) DI KOTA TARAKAN
}

\author{
Ariani \\ Mohamad Nur Utomo \\ Fakultas Ekonomi Universitas Borneo Tarakan, Tarakan, Indonesia \\ e-mail: adriana_amk@ymail.com
}

\begin{abstract}
This research aims to study the development and improvement strategy of competitiveness in facing competitive of free market ASEAN Economic Community (AEC) 2015, at SMEs in Tarakan City, North Kalimantan. Analytical method used is descriptive approaches, which is identify the various problems faced by SMEs and analyze them by using SWOT analysis and strategies formula to solve the model. The population of respondents includes all SMEs in Tarakan City, North Kalimantan. Sample method applies purposive sampling. Result of research in the form of development strategy model and improvement of competitiveness SMEs in facing is competitive globalness. Based on internal and external analysis of SMEs in Tarakan City, it can be obtained that the primary strategy is a strategy of growth in which SMEs Tarakan City strengthened the strength of SMEs which is to preserve the quality of raw materials, the legality/permit products included in the qualifications, the highly competitive price and the improvement of human resource development in SMEs in Tarakan City.
\end{abstract}

Keywords: competitive, competitiveness, development strategy, SMEs.

\begin{abstract}
ABSTRAK
Penelitian ini bertujuan untuk mengkaji strategi pengembangan dan peningkatan daya saing dalam menghadapi kompetitif pasar bebas ASEAN Economic Community (AEC) 2015, pada UMKM di kota Tarakan, Kalimantan Utara. Penelitian ini menggunakan data primer dan data sekunder.Metode analisis yang digunakan adalah pendekatan deskriptif, yaitu melakukan identifikasi berkaitan dengan berbagai masalah yang dihadapi oleh UMKM dan menganalisisnya dengan menggunakan analisis SWOT kemudian merumuskan model strategi untuk mengatasinya. Populasi responden meliputi seluruh UMKM yang berada di kota Tarakan, Kalimantan Utara. Metode sampel menggunakan purposive sampling. Hasil penelitian berupa model strategi pengembangan dan peningkatan daya saing UMKM dalam menghadapi kompetitif global. Kalimantan Utara. Berdasarkan analisis internal dan eksternal UMKM kotaTarakan dapat diperoleh bahwa yang menjadi strategi utama adalah strategi Growth (pertumbuhan) dimana UMKM kota Tarakan memanfaatkan seluruh kekuatan UMKM yaitu mempertahankan kualitas dari bahan baku, legalitas/ijin produk yang masuk dalam kualifikasi, harga yang tetap bersaing dan melakukan peningkatan SDM di dalam UMKM di kotaTarakan.
\end{abstract}

Kata kunci: kompetitif, dayasaing, strategi pengembangan, UMKM. 
Salah satu prioritas pembangunan dalam Rencana Kerja Pemerintah (RKP) adalah pengembangan Usaha Mikro Kecil dan Menengah (UMKM). Hal ini didasarkan fakta bahwa UMKM telah banyak berkontribusi dalam perekonomian nasional. Pengembangan Usaha Mikro, Kecil dan Menengah (UMKM) menjadi sangat strategis, karena potensinya yang besar dalam menggerakkan kegiatan ekonomi masyarakat, dan sekaligus menjadi tumpuan sumber pendapatan sebagian besar masyarakat dalam meningkatkan kesejahteraannya.

Beberapa temuan penelitian sebelumnya, Hamid dan Susilo, 2011; Sakur, 2011; Syahza, 2013; Irdayanti, 2012, menyatakan lemahnya daya saing UMKM disebabkan beberapa masalah antara lain: (1) Pemasaran; (2) Modal dan pendanaan; (3) Inovasi dan pemanfaatan teknologi informasi; (4) Pemakaian bahan baku; (5) Peralatan produksi; (6) Penyerapan dan pemberdayaan tenaga kerja; (7) Rencana pengembangan usaha; dan (8) Kesiapan menghadapi tantangan lingkungan eksternal. Kontribusi dan peran UMKM pada perekonomian nasional sangat berarti, namun dari sisi daya saing banyak kelemahan dan permasalahan bagi UMKM yang harus dibenahi untuk menghadapi persaingan baik di dalam negeri maupun secara global.

Peluang pengembangan UMKM di kota Tarakan provinsi Kallimantan Utara tentunya menjadi strategis. Posisi Wilayah Kalimantan Utara yang berbatasan langsung dengan negara jiran Malaysia, menjadikan UMKM harus berbenah diri dalam meningkatkan daya saingnya terlebih lagi dengan pemberlakuan perdagangan bebas pada ASEAN Economic Community (AEC) sejak tahun 2015. Untuk itu strategi pengembangan usaha bagi UMKM perlu dirumuskan dan dapat menjadi rekomendasibagi pemerintah danstakeholder lainnya dalam membuat kebijakan pemberdayaan UMKM di kota Tarakan.

Definisi usaha kecil menurut undang-undang nomor 20 tahun 2008 tentang usaha mikro, kecil dan menengah pada pasal 1 adalah usaha ekonomi produktif yang berdiri sendiri, yang dilakukan oleh orang perorangan atau badan usaha yang bukan merupakan anak perusahaan atau bukan cabang perusahaan yang dimiliki, dikuasai, atau menjadi bagian baik langsung maupun tidak langsung, dari usaha menengah atau usaha besar.

Menurut BPS UMKM di bedakan berdasarkan jumlah tenaga kerjanya yaitu industri tumah tangga dengan pekerja 1-4 orang, industri kecil dengan pekerja 5-19 orang, industri menengah dengan pekerja 20-99 orang, industri besar dengan pekerja 100 orang atau lebih. Menurut Chris Manning, et al (1991) sektor UKM adalah bagian dari sistem ekonomi kota dan desa yang belum mendapatkan bantuan ekonomi dari pemerintah atau belum mampu menggunakan bantuan yang telah disediakan atau telah menerima bantuan tetapi belum sanggup dikembangkan. Sektor UKM di Indonesia, umumnya mempunyai ciri-ciri sebagai berikut: Kegiatan usaha tidak terorganisasikan secara baik, karena timbulnya unit usaha tidak mempergunakan fasilitas/kelembagaan yang tersedia, tidak mempunyai izin usaha, pola kegiatan usaha tidak teratur baik dalam arti lokasi maupun jam kerja, pada umunya kebijakan pemerintah untuk membantu golongan ekonomi lemah tidak sampai ke sektor ini. Pada umumnya UKM di Indonesia masih dihadapkan pada berbagai permasalahan yeng menghambat kegiatan usahnya. Berbagai hambatan tersebut meliputi kesulitan pemasaran, keterbatasan finansial, keterbatasan SDM berkualitas, masalah bahan baku, keterbatasan teknologi, infrastruktur pendukung dan rendahnya komitmen pemerintah.

Studi yang dilakukan oleh International Labour Organization (ILO) seperti dikemukakan Sethuraman (1993) dalam Sriyana (2010), dijelaskan bahwa aktivitas-aktivitas UKM tidak terbatas pada pekerjaan-pekerjaan tertentu, tetapi bahkan juga meliputi berbagai aktivitas ekonomi yang antara lain ditandai dengan: mudah untuk dimasuki, bersandar pada sumberdaya lokal, usaha milik sendiri, opersinya dalam skala kecil, padat karya dan teknologinya bersifat adaptif, keterampilan 
dapat diperoleh di luar sistem sekolah formal, dan tidak terkena langsung oleh regulasi dan pasarnya bersifat kompetitif. Studi yang dilakukan ILO ini menyebutkan sektor UKM punya ciri: ukuran usaha kecil, kepemilikan keluarga, intensif tenaga kerja, status usaha individu, tanpa promosi, dan tidak ada hambatan masuk.

Daya saing dapat diciptakan maupun ditingkatkan dengan penerapan strategi bersaing yang tepat, salah satunya dengan pengelolaan sumber daya secara efektif dan efisien. Selain itu, penentuan strategi yang tepat harus disesuaikan dengan seluruh aktivitas dari fungsi perusahaan, sehingga akan menciptakan kinerja perusahaan sesuai dengan yang diharapkan bahkan lebih dan dapat menghasilkan nilai. Semua perusahaan, khususnya UKM bersaing untuk menjadi yang terdepan dalam era persaingan. Oleh karena itu, setiap UKM dituntut untuk memiliki daya saing yang tinggi, sehingga harus mulai memperbaiki diri. UKM yang memiliki daya saing tinggi ditandai dengan kemampuan sumber daya manusia (SDM) yang andal, penguasaan pengetahuan yang tinggi, dan penguasaan perekonomian.

Selanjutnya menurut Rahmana (2009), UKM perlu memanfaatkan TI untuk meningkatkan daya saingnya, mengingat di era globalisasi ini arena persaingan semakin kompetitif, dan bersifat mendunia. Salah satu strategi untuk meningkatkan daya saing UKM adalah dengan melalui pemanfaatan TI. Dengan pemanfaatan TI akan mendorong UKM untuk mendapatkan peluang ekspor dan peluang bisnis lainnya. Dengan kondisi tersebut kegiatan pengembangan UMKM perlu di arahkan untuk melakukan analisis daya saing dan merumuskan upaya-upaya peningkatan daya saing dalam rangka pembangunan daya saing dan perekonomian nasional. Mempertajam peningkatan daya saing usaha yang searah dengan persaingan usaha ke depan. Indonesia dengan jumlah penduduk yang besar dan terus bertambah, sangat membutuhkan keberadaan UMKM yang kuat, berdaya saing di pasar dalam negeri maupun global. UMKM adalah kunci bagi peningkatan kualitas hidup bangsa, sekaligus kunci bagi ketahanan perekonomian nasional. Perlu kebijakan yang didukung seluruh pemangku kepentingan, untuk menempatkan pasar dalam negeri sebagai basis pengembangan UMKM.

Beberapa temuan penelitian sebelumnya menyatakan lemahnya daya saing UMKM disebabkan beberapa masalah yang dihadapi oleh para UMKM. Hamid dan Susilo (2011) menyimpulkan dari hasil penelitiannya beberapa masalah yang dihadapi oleh UMKM di Provinsi DIY, antara lain: (1) Pemasaran; (2) Modal dan pendanaan; (3) Inovasi dan pemanfaatan teknologi informasi; (4) Pemakaian bahan baku; (5) Peralatan produksi; (6) Penyerapan dan pemberdayaan tenaga kerja; (7) Rencana pengembangan usaha; dan (8) Kesiapan menghadapi tantangan lingkungan eksternal.

Tujuan yang ingin dicapai dari pelaksanaan kegiatan penelitian ini adalah untuk menghasilkan satu model strategi pengembangan UMKM berbasis Daya Saing. Untuk mewujudkan hasil tersebut maka kegiatan utama akan dilaksanakan dalam dua langkah yakni; 1) identifikasi masalah-masalah yang dihadapi UMKM, dan2) penyusunan model strategi pengembangan UMKM berbasis daya saing. Pada langkah pertama, kegiatan yang akan dilaksanakan adalah mengumpulkan informasitentang masalah-masalah yang dihadapi UMKM berkaitan dengan peningkatan daya saing.

Informasi diperoleh dari pengumpulan data yaitu data primer dan data sekunder. Data primer diperoleh dengan metode survey dengan melakukan wawancara pada informan dan penyebaran kuesioner pada responden. Informan adalah pihak-pihak yang mengetahui informasi tentang UMKM seperti misalnya pegawai atau staf Dinas Perindagkop dan UKM atau informan lembaga-lembaga lainnya yang berkepentingan terhadap UMKM. Sedangkan kuesioner diberikan pada UMKM sebagai 
responden penelitian. Populasi dalam penelitian ini adalah UMKM yang berada dikota Tarakan. Penentuan sampel responden menggunakan metode purposive sampling. Sampel dipilih berdasarkan pertimbangan-pertimbangan tertentu, sedangkan pertimbangan yang diambil itu berdasarkan tujuan tertentu (Rianse, 2008:208). Kriteria sampel UMKM yang digunakan adalah sebagai berikut:

1. Memiliki asset Rp 50.000.000-Rp 10.000.000.000.

2. Memiliki omzet maksimal $50 \mathrm{M}$ pertahun.

3. Memiliki tenaga kerja 5-250 orang.

4. Usaha berbasis pengolahan baik home industry, pertanian, dan perikanan.

Data sekunder berupa informasi perkembangan UMKM di kota Tarakan dari berbagai sumber. Data yang diperoleh kemudian di analisis dengan menggunakan metode deskriftif. Analisis deskriftif menggunakan Tabulasi Frekuensi dan grafik yang menghasilkan gambaran permasalahan UMKM dikota Tarakan. Dari hasil analisis deskriftif kemudian dilanjutkan langkah kedua merumuskan dan menyusun model strategi pengembangan UMKM dengan menggunakan analisis SWOT (Strengths, Weaknesses, Opportunities, Threats).

Secara ringkas, langkah dan target dari masing-masing tahapan dan setiap kegiatan yang akan dilaksanakan dapat digambarkan dengan diagram berikut:

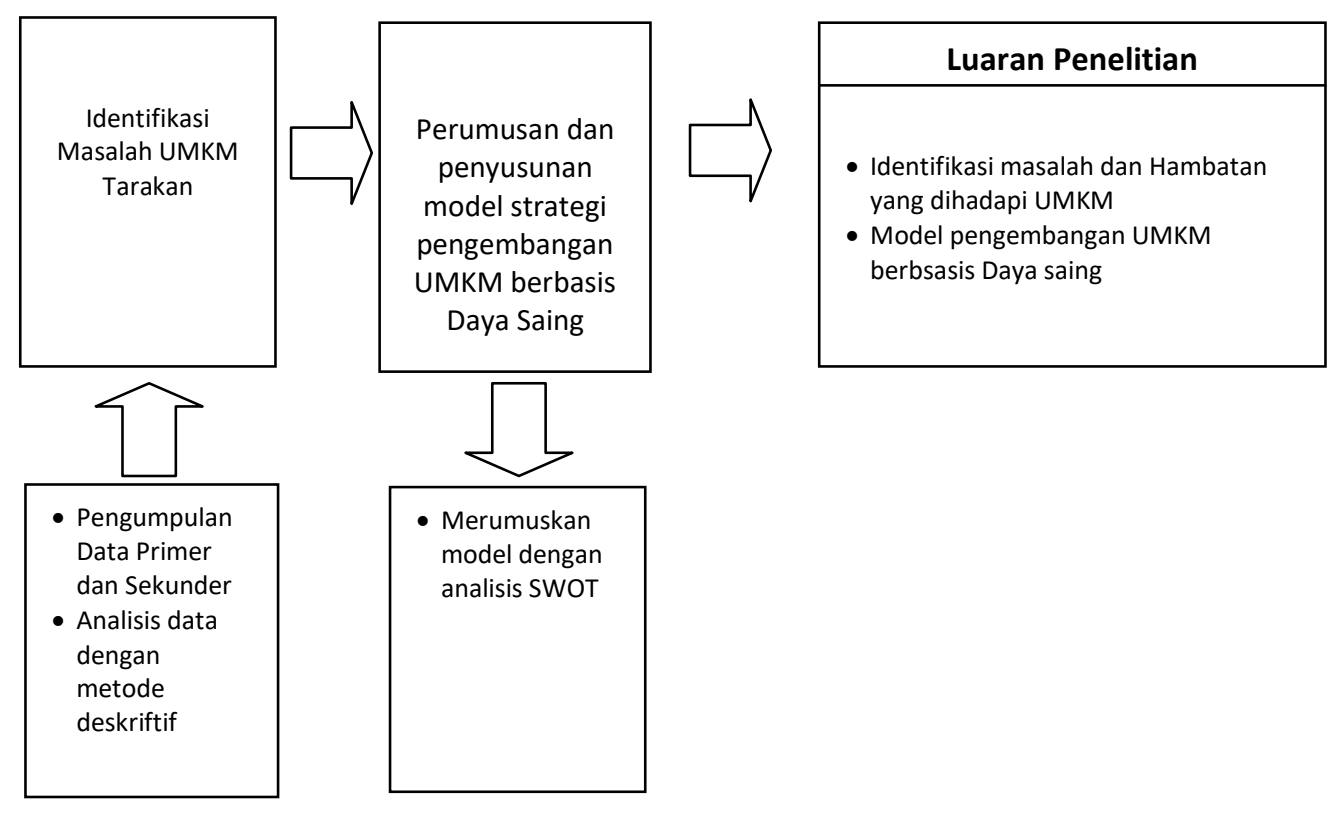

Gambar 1. Bagan alir penelitian model pengembangan UMKM berbasis daya saing di Tarakan

Pada penelitian ini bertujuan merumuskan model strategi pengembangan UMKM berbasis daya saing. Alat analisis yang digunakan dalam penelitian adalah analisis deskriftif dan analisis SWOT. Analisis deskriptif digunakan untuk mengolah data-data yang dikumpulkan baik berupa data primer dan sekunder. Analisis ini bertujuan untuk mengidentifikasi masalah-masalah serta persoalan yang di hadapi oleh UMKM. Analisis dengan menggunakan bantuan tabulasi frekuensi dan grafik. 
Analisis SWOT adalah adalah metode perencanaan strategis yang berfungsi untuk mengevaluasi kekuatan, kelemahan,peluang, dan ancaman suatu perusahaan. Proses ini melibatkan penentuan tujuan yang spesifik dari spekulasi bisnis dan mengidentifikasi faktor internal dan eksternal yang mendukung dan yang tidak dalam mencapai tujuan tersebut. Analisa SWOT berguna untuk menganalisa faktor-faktor di dalam organisasi yang memberikan andil terhadap kualitas pelayanan atau salah satu komponennya sambil mempertimbangkan faktor-faktor eksternal. Proses pengambilan keputusan strategis selalu berkaitan dengan pengembangan misi, tujuan, strategis, dan kebijakan organisasi. Dengan demikian perencana strategis (strategic planner) harus menganalisis faktor-faktor strategis organisasi (kekuatan, kelemahan, peluang dan ancaman) dalam kondisi yang ada saat ini.

1. Kekuatan (Strengths): karakteristik bisnis, atau proyek yang memberikan keuntungan lebih dari orang lain.

2. Kelemahan/ Keterbatasan (Weaknesses): adalah karakteristik yang menempatkan bisnis/ proyek di posisi yang kurang menguntungkan dibandingkan dengan orang lain.

3. Peluang (Opportunities): peluang eksternal untuk meningkatkan kinerja (misalnya membuat keuntungan yang lebih besar) di lingkungan.

4. Ancaman (Threats): unsur eksternal dalam lingkungan yang dapat menyebabkan masalah bagi bisnis atau proyek.

\section{HASIL DAN PEMBAHASAN}

Populasi atau responden dalam penelitian ini yaitu masyarakat yang menjadi anggota/pelaku UMKM di kota Tarakan yang tersebar di seluruh kecamatan kota Tarakan. Pada penelitian ini kuesioner yang disebar sebanyak 100 responden yang menjadi pelaku UMKM yang tersebar di Kota Tarakan.

Potensi Usaha Mikro Kecil dan Menengah (UMKM) kota Tarakan yang cukup besar, yang didukung oleh sumber daya alam yang dimiliki oleh kota Tarakan yang berlimpah telah memberikan kontribusi yang signifikan terhadap perekonomian masyarakat di kota Tarakan. Namun pada saat yang sama tidak dapat dipungkiri bahwa kondisi UMKM di kota Tarakan masih lemah dalam berbagai aspek usaha, diantaranya pada aspek kemampuan SDM, sarana dan prasarana, permodalan maupun dari segi pemasarannya. Oleh sebab itu pemerintah kota Tarakan, melalui SKPD terkait khususnya Bidang Perindustrian, Dinas Perindagkop dan UMKM terus melaksanakan upaya pembinaan dan pemberdayaan terhadap UMKM.

Banyak potensi yang dapat dikembangkan di Tarakan diantaranya pada sektor kelautan dan perikanan, sektor pariwisata, industri dan perdagangan serta investasi di sektor energi. Dengan berbagai potensi tersebut peluang pengembangan UMKM di kota Tarakan provinsi Kallimantan Utara menjadi strategis. Posisi Wilayah Kalimantan Utara yang berbatasan langsung dengan negara Malaysia, menjadikan UMKM harus berbenah diri dalam meningkatkan daya saingnya terlebih lagi dengan pemberlakuan perdagangan bebas pada ASEAN Economic Community (AEC) sejak tahun 2015. Untuk itu strategi pengembangan usaha bagi UMKM perlu dirumuskan dan dapat menjadi rekomendasi bagi pemerintah dan stakeholder lainnya dalam membuat kebijakan pemberdayaan UMKM di kota Tarakan. 


\section{Identifikasi Hambatan yang di Hadapi dalam Mengembangkan Usaha pada UMKM di Kota Tarakan}

Hambatan dan masalah yang dihadapi dalam mengembangkan usaha pada UMKM di kota Tarakan pada umumnya dapat disebabkan oleh faktor internal dan eksternal. Dimana yang bersifat internal yaitu meliputi dana keterbatasan ketersediaan tenaga kerja atau SDM, manajemen yang masih sangat sederhana dan belum efektif sehingga kurang efisien, adanya kekurangan atau keterbatasan dalam segi permodalan, kurangnya sarana dan prasarana serta lemahnya ppengetahuan tentang sistem pemasaran dan kurangnya infrastruktur yang kurang mendukung.

Permasalahan utama penyebab lemahnya pertumbuhan UMKM yaitu dari segi permodalan dan ketersedian sarana dan prasarana penunjang bagi peningkatan usaha pada bidang UMKM di kota Tarakan. Banyak sekali UMKM yang dapat membuka usaha namun tidak dapat mempertahankan usahanya dengan alas an keterbatasan modal yang terkadang disebabkan oleh lemahnya daya beli masyarakat dan informasi serta pengetahuan tentang berwirausaha bagi UMKM yang ada di kota Tarakan ini khususnya.

Beberapa permasalahan dan hambatan yang ditemui baik dalam hal manajemen secara internal dan eksternal maupun dalam pelaksanaan kegiatan usaha yang antara lain sebagai berikut:

1) Terbatasnya modal yang dimiliki oleh pelaku UMKM.

2) Masih rendahnya pengetahuan dan pemahaman pelaku UMKM dalam mengembangkan dan mempertahankan usaha di dunia bisnis.

3) Kurangnya ketersedian sarana dan prasarana yang dibutuhkan oleh pelaku UMKM dalam membantu pengembangan dan peningkatan usahanya.

4) Adanya hambatan secara eksternal seperti kesediaan tenaga listrik yang dianggap mengganggu kegiatan operasional dari UMKM di kota Tarakan.

5) Kurangnya pemahaman dari pelaku UMKM tentang strategi, sistem dan proses pemasaran bagi hasil produksinya.

6) Kurang pahamnya mengenai birokrasi dalam dunia usaha untuk dapat menembus pasar yang lebih luas dari pasar lokal yang telah mereka lakukan dan minimnya atau sedikitnya informasi mengenai pengembanganusaha bagi UMKM di kota Tarakan.

7) Kemampuan dalam penggunaan atau penerapan teknologi dalam menunjang peningkatan usaha dan kemampuan penerapan standar produk UMKM yang masih terbatas.

8) Akses sarana informasi yang dapat diakses oleh masyarakat masih terbatas dan kebijakan yang masih terlihat bias bagi pelaku UMKM di Kota Tarakan, sehingga mengurangi ruang gerak bagi pelaku UMKM kota Tarakan.

\section{Analisis Identifikasi dan Deskripsi Pengembangan Usaha Pada UMKM di Kota Tarakan}

Analisis ini mencakup beberapa aspek yang menyangkut pada rumusan strategi pengembangan usaha yang efektif untuk meningkatkan daya saing dalam menghadapi kompetitif pasar bebas, pada UMKM di Kota Tarakan. Dimana pada tahap ini yang perlu diperhatikan adalah aspek pemasaran, aspek modal dan pendanaan usaha, aspek pemanfaatan teknologi informasi dan inovasi, aspek pemakaian bahan baku, aspek peralatan produksi, aspek penyerapan dan pemberdayaan tenaga kerja, aspek organisasi dan manajemen usaha, aspek birokrasi dan peran pemerintah dan aspek eksternalitas dan lain-lain. 


\section{1) Aspek Pemasaran}

Pada penelitian aspek pemasaran ini ada beberapa hal yang menjadi pertimbangan bagi responden yaitu segi produk, harga, tempat, promosi, dan lain-lainnya terkait pemasaran. Informasi secara lengkap mengenai segi produk responden dapat dilihat pada Tabel 1.

Tabel 1. Aspek Pemasaran UMKM Kota Tarakan dari Segi Produk

\begin{tabular}{lccc}
\hline \multirow{2}{*}{\multicolumn{1}{c}{ Produk }} & \multicolumn{2}{c}{ Frekuensi } & Persen \\
\cline { 2 - 4 } & Ya & Tidak & $\%$ \\
\hline Memiliki kemasan & 75 & 25 & 75 \\
Terdapat ijin/legalisasi produk & 95 & 5 & 95 \\
Produk dihasilkan melalui desain & 43 & 57 & 43 \\
Melakukan pemeriksaan kualitas produk & 98 & 2 & 98 \\
Terdapat layanan purna jual dan garansi & 30 & 70 & 30 \\
Produk dibuat berdasarkan order/pesanan & 59 & 41 & 59 \\
Memiliki merek yang dipatenkan & 43 & 57 & 43 \\
Terdapat diferensiasi/keragaman & 74 & 26 & 74 \\
Terdapat segmentasi produk (seperti wilayah, usia, & & & \\
tingkat pendapatan, dil) & 37 & 63 & 37 \\
\hline Sumber : Data primer diolah, 2016 & \multicolumn{3}{c}{}
\end{tabular}

Berdasarkan Tabel 1, maka produk yang terdapat pada aspek pemasaran tersebut dapat dilihat jika produk tersebut telah memiliki kemasan yang sesuai dengan prasyarat yang seharusnya sebesar 75\% dari 100 responden berarti sebagian besar UMKM telah memiliki kemasan dalam produknya. 95\% UMKM yang menjadi responden telah memiliki izin/legalisasi produknya, 93\% telah melalui pemeriksaan produk dari pihak yang berwenang atau dinas terkait, namun jika dilihat dari segi desain masih sekitar $43 \%$ yang melaluinya, layanan purna jual dan garansi dalam produk masih sangat rendah yaitu sebesar $30 \%$ saja, $59 \%$ produk yang dihasilkan masih sesuai dengan pesanan atau by order, beberapa usaha masih belum mematenkan merk dari produknya yang dapat dilihat hanya sekitar $43 \%$ saja yang telah mematenkan merk dari produk. Dari sisi diferensiasi/ keragaman sudah cukup baik yang ditunjukkan sebesar $74 \%$, namun sebagian besar segmentasi pasar masih belum jelas yang ditunjukan pada besaran yang kurang dari setengah atau sebesar $37 \%$ saja.

Tabel 2. Aspek Pemasaran UMKM KotaTarakan dari Segi Harga

\begin{tabular}{|c|c|c|c|}
\hline Harga & \multicolumn{2}{|c|}{ Frekuensi } & Persen (\%) \\
\hline \multicolumn{4}{|l|}{ Harga produk ditetapkan berdasarkan } \\
\hline a. Biaya produksi & \multicolumn{2}{|c|}{66} & 66 \\
\hline b. Harga penawaran & \multicolumn{2}{|c|}{4} & 4 \\
\hline c. Harga pasar & \multicolumn{2}{|c|}{30} & 30 \\
\hline d. Lain-lain & \multicolumn{2}{|c|}{0} & 0 \\
\hline Total & \multicolumn{2}{|c|}{100} & 100 \\
\hline Memiliki daftar harga & 56 & 44 & 56 \\
\hline Memberikan diskon/potongan harga & 62 & 38 & 62 \\
\hline $\begin{array}{l}\text { Pembayaran dapat ditangguhkan (kredit) } \\
\text { Jika pertanvaan no } 3 \text { jawaban (va). memiliki }\end{array}$ & 14 & 86 & 14 \\
\hline persyaratan kredit & 4 & 96 & 4 \\
\hline
\end{tabular}

Sumber : Data primer diolah, 2016 
Jika dilihat dari segi harga dapat dikatakan bahwa yang mempengaruhi harga adalah biaya produksi yaitu sebesar $66 \%$, sedangkan harga pasar dan harga penawaran tidak ada pengaruh dalam penentuan harga produk. Kelemahan dalam harga yaitu kurang memperhatikan penggunaan daftar harga yaitu sebesar $56 \%$, sedikit berani dalam pemberian potongan harga yang ditunjukkan sebesar $62 \%$, namun sebagian besar dari responden UMKM tidak memberikan pembayaran yang ditangguhkan (kredit) yang dijelaskan dari 14\% responden saja yang mau memberikan kredit.

Tabel 3. Aspek Pemasaran UMKM Kota Tarakan dari Segi Tempat

\begin{tabular}{lrrr}
\hline \multirow{2}{*}{\multicolumn{1}{c}{ Tempat }} & \multicolumn{2}{c}{ Frekuensi } & Persen \\
\cline { 2 - 4 } & Ya & Tidak & $\%$ \\
\hline Lokasi usaha dianggap strategis & 83 & 17 & 83 \\
Lokasi usaha mudah diakses & 92 & 8 & 92 \\
Lokasi Usaha dapat dilihat konsumen & 91 & 9 & 91 \\
Memiliki gudang/logistik persediaan & 50 & 50 & 50 \\
\hline
\end{tabular}

Sumber : Data primer diolah, 2016

Tempat merupakan salah satu penentu dalam usaha, apakah tempat usaha tersebut harus mendekati bahan baku, pasar/konsumen atau harus mendekati kedua-duanya sekaligus. Maka dapat dilihat dari Tabel 3. Tempat ditentukan oleh lokasi usaha yang mudah diakses dengan nilai $92 \%$, lokasi yang strategis dalam suatu usaha yaitu sebesar $83 \%$, dan letak lokasi usaha yang dapat dilihat konsumen sebesar $91 \%$. Sementara itu kepemilikan gudang/logistik persediaan dianggap bukan merupakan faktor penentu dalam aspek pemasaran dari segi tempat karena ekspektasinya hanya sebesar $50 \%$, dapat diartikan bahwa keberhasilan atau pertumbuhan usaha tidak dapat ditentukan atas dasar kepemilikan gudang tapi lebih kepada lokasi usaha yang trategis, dekat dengan konsumen atau mudah dijangkau oleh konsumen.

Tabel 4. Aspek Pemasaran UMKM Kota Tarakan dari Segi Promosi

\begin{tabular}{lcc}
\multicolumn{1}{c}{ Promosi } & Frekuensi & Persen (\%) \\
\hline $\begin{array}{l}\text { Promosi produk melalui media Iklan } \\
\text { Selalu memberikan Informasi produk pada }\end{array}$ & 22 & 22 \\
konsumen jika ada produk baru atau peningkatan & 69 & 69 \\
kualitas & & 38 \\
Memiliki Tenaga penjualan (sales) & 38 & 95 \\
Lokasi Usaha dapat dilihat konsumen & 95 & \\
Wilayah Promosi dan penjualan & & 98,5 \\
$\quad$ a. Lokal & 92 & \\
b. Nasional & 2 & \\
c. Lokal+Nasional & 4 & \\
d. Lokal+Internasional & 2 &
\end{tabular}

Sumber : Data primer diolah, 2016

Berdasarkan hasil dari Tabel 4 promosi, penggunaan promosi produk melalui media iklan tidak menjadi pilihan bagi sebagian besar dari responden dan dapat dilihat dari hasil survei yang hanya menunjukan sebesar $22 \%$ saja yang menggunakan media iklan tersebut. Kebanyakan dari responden melakukan penjualansecara langsung dengan selalu membuat inovasi sebesar $69 \%$, dan 
menyampaikan secara langsung sesuai dengan hasil survei 95\%. Wilayah promosi dan penjualan rata-rata 98,5\% masih pada wilayah lokal walau sebagian kecil sudah ada secara nasional dan internasional. Menurut hasil survei hal tersebut dikarenakan ada hal-hal yang menghambat dalam pelaksanaan pengembangan usaha seperti keterbatasan dari segi modal dan jaringan informasi serta sarana dan prasarana yang digunakan serta yang diketahui masih terbatas.

Tabel 5. Aspek Pemasaran UMKM Kota Tarakan dari Segi Lainnya Terkait Pemasaran

\begin{tabular}{lcc}
\multicolumn{1}{c}{ Lain-lainnya Terkait Pemasaran } & Frekuensi & Persen (\%) \\
\hline Penjualan di atur asosiasi persainganusaha & 13 & 13 \\
Memiliki Informasi pasar pembeli di luar negeri & 2 & 2 \\
Memiliki hubungan dengan pengusaha besar terkait penjualan & 28 & 28 \\
produk atau pembelian bahan baku & & \\
Jika pertanyaan no.3 jawaban (ya), harga dan sistem pembayaran & 15 & 15 \\
ditentukan pengusaha besar & & \\
Sistem Penjualan (boleh lebih dari satu) & 40 & \\
(1) Retail, & 38 & \\
(2) Distributor & 22 & \\
(3) Retail+Distributor & & 43 \\
Target utama pasar & & \\
a. Masyarakat golongan bawah (penghasilan dibawah Rp 5 juta & 43 & 27 \\
$\quad$ perbulan) & & \\
b. Masyarakat golongan menengah(penghasilan Rp 5-10 juta & 27 & 13 \\
$\quad$ perbulan) & & \\
c. Masyarakat golongan tinggi (penghasilan diatas Rp 10 juta & 13 & \\
$\quad$ perbulan) & 17 & 64 \\
d. Memenuhi order dari distributor/eksportir/pedagang besar & & \\
Tingkat persaingan usaha: & 8 & \\
Rendah & 64 & \\
Sedang & 28 & \\
Tinggi & & \\
\hline Sumber:Data primer diolah 2016 & & \\
\end{tabular}

Sumber : Data primer diolah, 2016

Dari penunjang lain-lainnya pada aspek pemasaran sesuai Tabel 5, yang lebih menjadi fokus dari responden adalah sistem penjualan sebesar $85,3 \%$ dipengaruhi oleh sistem retail dan distributor. Sedangkan tingkat persaingan usaha dianggap biasa-biasa saja atau sedang yang ditunjukkan dengan persentase sebesar 64\%. Target utama dari UMKM adalah masyarakat golongan bawah dan menengah, golongan di atas itu hanya sebagai user saja yang disebabkan efek lainnya, sedangkan keterkaitan dengan kolega dianggap tidak terlalu berpengaruh bagi pelaku UMKM di kota Tarakan. Serta informasi pasar luar negeri dianggap sulit agi para UMKM karena bukan usaha yang besar sehingga jaringan untuk kesana tidak menjadi fokus bagi pelaku UMKM tersebut.

\section{2) Aspek Modal dan Pendanaan Usaha}

Aspek modal dan pendanaan usaha disini berdasarkan hasil perhitungan jika dilihat dari sumber modal sebagian besar sekitar $85 \%$ berasal dari modal sendiri dan pinjaman, dan sisanya sebesar $15 \%$ diperoleh dari hasil kerjasama dan bantuan hibah seperti adanya pendampingan 
UMKM dari dinas terkait atau dari BUMN yang ada di kota Tarakan. Modal tambahan yang berasal dari kerjasama sangat kecil sekali karena banyak yang beranggapan bahwa usaha dari UMKM ini keuntungannya sangat kecil dan hanya beberapa UMKM saja yang melakukan hal tersebut.

Tabel 6. Aspek Modal dan Pendanaan Usaha UMKM Kota Tarakan

\begin{tabular}{lcc}
\multicolumn{1}{c}{ Aspek Modal dan Pendanaan Usaha } & Frekuensi & Persen (\%) \\
\hline Masih membutuhkan tambahan modal & 74 & 74 \\
Memiliki akses pada lembaga keuangan (bank atau non-bank) & 43 & 43 \\
$\begin{array}{l}\text { Berpengalaman meminjam dana pada lembaga keuangan (bank dan non- } \\
\text { bank) }\end{array}$ & 46 & 46 \\
Memiliki asset yang dapat digunakan sebagai jaminan utang yang layak & 33 & 33 \\
Mengetahui Informasi kredit Lembaga Keuangan (bank dan non-bank) & 34 & 34 \\
Mengetahui suku bunga pinjaman lembaga keuangan (bank dan non-bank) & 23 & 23 \\
$\begin{array}{l}\text { Mengetahui prosedur pengajuan kredit lembaga keuangan (bank dan non- } \\
\text { bank) }\end{array}$ & 46 & 46 \\
Mendapatkan kepastian pemberian kredit dari lembaga keuangan (bank & & 24 \\
dannon-bank) & 24 & 24 \\
\hline
\end{tabular}

Sumber : Data primer diolah, 2016

Berdasarkan data dari Tabel 6, jika ditanya apakah masih membutuhkan tambahan modal dalam pengembangan usahanya $74 \%$ responden menyatakan ya dan tambahan modal rata-rata sebagian besar menyatakan digunakan untuk penambahan biaya usaha dan lain-lain. Sebagian lagi yaitu sebesar $26 \%$ sebagai tambahan pembelian bahan baku dan peralatan produksi.

Bisa dikatakan sebagian besar responden tidak memahami mengenai prosedur dan birokrasi/administrasi dalam meminjam uang di bank dan non bank.Karena masih banyak dari responden yang tidak memiliki pengalaman dalam meminjam pada lembaga keuangan bank dan non bank, tidak faham dan kurang memiliki akses mengenai lembaga keuangan bank dan non bank. Sehingga apa itu suku bunga pinjaman, prosedur pengajuan kredit sampai mengenai kepastian standar mendapatkan kredit pun sebagian besar dari responden masih belum mengetahui karena minim/kurangnya informasi mengenai hal tersebut.

\section{3) Aspek Pemanfaatan Teknologi Informasi dan Inovasi}

Pemanfaatan teknologi dan inovasi merupakan suatu alat penunjang dalam perkembangan usaha dari UMKM di kota Tarakan, sehingga dapat dilihat respon dari responden mengenai beberapa indikator pertanyaan yang ada pada Tabel 7 .

Tabel 7. Aspek Pemanfaatan Teknologi Informasi dan Inovasi

\begin{tabular}{lcc}
\multicolumn{1}{c}{ Aspek Pemanfaatan Teknologi Informasi dan Inovasi } & Frekuensi & Persen (\%) \\
\hline Dalam usaha menggunakank omputer & 41 & 41 \\
Ada upaya-upaya mendesain produk baru yg lebih berkualitas & 67 & 67 \\
Melakukan perubahan pelayanan pada konsumen & 47 & 47 \\
Mencari pasar baru/peluang baru & 72 & 72 \\
Mencari pembelian bahan baku yang lebih baik & 93 & 93 \\
\hline
\end{tabular}

Sumber : Data primer diolah, 2016 
Berdasarkan Tabel 7 aspek pemanfaatan teknologi informasi dan inovasi dalam usaha menggunakan komputer diperoleh sebesar $41 \%$ yang artinya bahwa penggunaan komputer dalam usaha UMKM masih tergolong sedikit responden masih banyak yang menggunakan asministrasi sederhana dalam kegiatan operasionalnya, namun ada upaya mendesain produk baru yang lebih berkualitas sebesar $67 \%$ dan sistem pelayanan tidak mengalami perubahan signifikan ditunjukkan oleh hasil survei sebesar 47\%. Pada aspek ini lebih menitik beratkan teknologi sebagai alat mencari pasar baru/peluang baru sebesar $72 \%$ dan mencari pembelian bahan baku yang lebih baik dengan nilai presentase sebesar $93 \%$.

\section{4) Aspek Pemakaian Bahan Baku}

Bahan baku merupakan salah satu pertimbangan dalam dunia usaha, baik dalam hal penggunaan, ketersediaan maupun harga perolehan dari bahan baku itu sendiri. Karena sedikit banyaknya akan mempengaruhi dari penentuan harga produk yang diproduksi oleh suatu usaha khususnya UMKM.

Tabel 8. Aspek Pemakaian Bahan Baku

\begin{tabular}{lcc}
\hline \multicolumn{1}{c}{ Aspek Pemakaian Bahan Baku } & Frekuensi & Persen (\%) \\
\hline Bahan baku mudah diperoleh & 95 & 95 \\
Pembelian kontinuitas bahan baku mudah diperoleh & 83 & 83 \\
Harga bahan baku stabil & 68 & 68 \\
Harga bahan baku berfluktuatif (naik-turun) & 47 & 47 \\
Harga bahan baku sangat dipengaruhi nilai kurs dolar & 22 & 22 \\
Kualitas bahan baku konsisten & 96 & 96 \\
Terdapat jaminan dalam pembelian bahan baku & 71 & 71 \\
\hline
\end{tabular}

Sumber : Data primer diolah, 2016

Dilihat dari Tabel 8, aspek pemakaian bahan baku di sini dapat dilihat dari frekuensi masingmasing bahwa perolehan bahan baku sebesar $95 \%$ yang menyatakan dalam usaha tersebut sangat mudah dalam mendapatkan bahan baku, sampai pada pembelian yang kontinuitas pun tetap tersedia dilihat dari data responden sebesar $83 \%$ dan harga dari bahan baku relatif tetap menurut responden sebesar $68 \%$. Harga bahan baku tidak fluktuatif relatif tetap karena hanya sebagian kecil responden saja yang menyatakan hal tersebut sebesar $47 \%$ dan sebagian kecil responden sekitar $22 \%$ yang menyatakan nilai kurs berpengaruh jadi sebagian besar menyatakan tidak dipengaruhi oleh nilai kurs. Jadi dapat dikatakan bahwa kualitas dari bahan baku yang digunakan konsisten karena terdapat jaminan dalampembelian bahan baku produknya yang didasarkan atas pernyataan sebesar $71 \%$.

\section{5) Aspek Peralatan Produksi}

Aspek peralatan produksi merupakan salah satu asset bagi para pelaku UMKM di kota Tarakan baik itu yang tradisional maupun yang sudah modern atau menggunakan teknologi canggih. Peralatan produksi dapat berupa barang bergerak maupun barang tak bergerak, tanpa peralatan produksi yang memadai akan sulit bagi pelaku UMKM untuk dapat tumbuh berkembang dalam menjalankan usahanya. Aspek peralatan produksi tersebut dapat dilihat dalam Tabel 9. 
Tabel 9. Aspek Peralatan Produksi

\begin{tabular}{lcc}
\hline \multicolumn{1}{c}{ Aspek Peralatan Produksi } & Frekuensi & Persen (\%) \\
\hline Peralatan produksi masih tradisional & 43 & 43 \\
Melakukan perubahan peralatan yang lebih canggih dan efisien & 94 & 94 \\
Memiliki peralatan produksi pelengkap lainnya & 100 & 100 \\
Paralatan produksi aman digunakan & 99 & 99 \\
Memiliki alat transportasi & 79 & 79 \\
Biaya operasional peralatan produksi mahal & 47 & 47 \\
\hline
\end{tabular}

Sumber : Data primer diolah, 2016

Berdasarkan Tabel 9, responden menyatakan setuju atau penting yaitu sebesar $100 \%$ bahwa melakukan perubahan alat yang lebih canggih dan efisien serta memiliki peralatan produksi pelengkap lainnya. Sisanya menganggap penggunaan peralatan produksi tradisional masih layak yaitu sebesar $43 \%$ dan $47 \%$ responden masih menganggap bahwa biaya operasional peralatan produksi canggih itu mahal dan sebagian besar yaitu $53 \%$ menyatakan tidak.

Selain barang tak bergerak seperti mesin produksi tidak kalah penting bagi para pelaku usaha UMKM yaitu barang bergerak seperti Kendaraan roda dua (sepeda motor) dan kendaraan roda empat (mobil), kapal laut, kapal udara atau dengan kata lain adalah alat transportasi yang berperan sebagai pendukung dalam usaha UMKM, sebesar $79 \%$ responden menyatakan alat transportasi tersebut sangat penting dan mampu mempengaruhi pendapatan dan harga dari barang produksi dari UMKM yang ada di kota Tarakan baik itu lokal, antar pulau, nasional maupun secara internasional.

\section{6) Aspek Penyerapan dan Pemberdayaan Tenaga Kerja}

Pengembangan UMKM di kota Tarakan diharapkan mampu memberi sumbangsih bagi kota Tarakan khususnya dalam hal penggurangan tingkat pengangguran dan kemiskinan. Sehingga dari UMKM ini dapat dilihat besarnya aspek dari penyerapan dan pemberdayaan tenaga kerja. Hal tersebut dapat dilihat dari Tabel 10.

Tabel 10. Aspek Penyerapan dan Pemberdayaan Tenaga Kerja

\begin{tabular}{lcc}
\hline \multicolumn{1}{c}{ Aspek Penyerapan dan Pemberdayaan Tenaga Kerja } & Frekuensi & Persen (\%) \\
\hline Tenaga kerja rata-rata memiliki pengalaman & 39 & 39 \\
Tenaga kerja memiliki keahliankhusus & 36 & 36 \\
Pergantian Tenaga kerja tinggi (mengundurkan diri dII) & 21 & 21 \\
Perekrutan tenaga kerja mudah & 95 & 95 \\
Terdapat upaya peningkatan keahliantenaga kerja & 86 & 86 \\
\hline
\end{tabular}

Sumber: Data primer diolah, 2016

Dalam dunia usaha UMKM dikota Tarakan berdasarkan Tabel 10, kebanyakan responden menyatakan bahwa perekrutan tenaga kerja sangat mudah yaitu sebanyak $95 \%$. Kelemahannya adalah bahwa pelaku UMKM sulit memiliki tenaga kerja yang memiliki pengalaman dan keahlian khusus. Namun dalam turn over tenaga kerjanya tidak besar atau bisa dikatakan tenaga kerjanya mampu bertahan lama dalam satu tempat kerja, sehingga pengguna tenaga kerja dalam hal ini adalah pelaku usaha UMKM memberikan peningkatan keahlian bagi tenaga kerjanya agar mampu bersaing dengan usaha-usaha yang sama dalam pasar persaingan tersebut. 


\section{7) Aspek Organisasi dan Manajemen Usaha}

Keterlibatan pelaku usaha UMKM dalam aspek organisasi dan manajemen usaha dapat dilihat pada Tabel 11.

Tabel 11. Aspek Organisasi dan Manajemen Usaha

\begin{tabular}{lcc}
\multicolumn{1}{c}{ Aspek Organisasi dan Manajemen Usaha } & Frekuensi & Persen (\%) \\
\hline Terlibat dalam asosiasi usaha (Paguyuban) & 19 & 19 \\
Memiliki rencana pengembangan Usaha & 88 & 88 \\
Memisahkan keuangan usaha dan pribadi & 96 & 96 \\
Melakukan antisipasi resiko pencurian dan penyimpangan & & \\
kecurangan dari karyawan & 91 & 91 \\
\hline
\end{tabular}

Sumber: Data primer diolah, 2016

Tabel 11 menyatakan bahwa responden yang menjadi pelaku usaha UMKM 81\% belum terlibat dalam asosiasi usaha (Paguyuban) yang ada di kota Tarakan, permasalahnya di sini sangat sedikit pemahaman responden mengenai manfaat dari paguyuban tersebut bagi usahanya. Namun dari sisi manajemennya sebagian besar responden telah mampu memisahkan keuangan usaha dan pribadi yang ditunjukan sebesar $96 \%$ responden telah memisahkan antara modal usaha dan prive. Selain itu sebagian besar responden telah membuat rencana pengembangan usaha serta melakukan antisipasi resiko pencurian dan penyimpangan kecurangan yang disebabkan oleh karyawannya.

\section{8) Aspek Birokrasi dan Peran Pemerintah}

Bagi para pelaku UMKM di kota Tarakan rata-rata tidak mau dipusingkan oleh masalah birokrasi dan mempertanyakan peran pemerintah tentang andil pemerintah terhadap peningkatan usahanya. Hal ini dapat dilihat pada Tabel 12 mengenai aspek birokrasi dan peran pemerintah kota Tarakan terhadap pengembangan UMKM kota Tarakan.

Tabel 12. Aspek Birokrasi dan Peran Pemerintah

\begin{tabular}{lcc}
\hline \multicolumn{1}{c}{ Aspek Birokrasi dan Peran Pemerintah } & Frekuensi & Persen (\%) \\
\hline Proses perizinan usaha cukup mudah & 96 & 96 \\
Terdapat Pungutan atas usaha yang dilakukan & 59 & 59 \\
Jika pertanyaan no.2 (ya) pungutan terlalu membebankan & & \\
(mahal) & 8 & 8 \\
Pernah Ikut dilibatkandalamkebijakan UMKM & & 39 \\
Infrastruktur yang dibangun pemerintah memadai dan & 97 & 97 \\
membantu jalannya usaha & 14 & 14 \\
Terdapat pendanaan bunga lunak oleh pemerintah & 14 & 14 \\
Jika pertanyaan no. 6 (ya) prosedur pendanaan mudah & & \\
$\begin{array}{l}\text { Pernah memperoleh pembinaan program kemitraan usaha dari } \\
\text { pemerintah }\end{array}$ & 25 & 25 \\
$\begin{array}{l}\text { Pemerintah memberikan perlindungan usaha baik dari monopoli } \\
\text { maupun dari ekspansi eksternal }\end{array}$ & 27 & 27 \\
\hline Sumber : Data primer diolah 2016 & &
\end{tabular}


Sebagian besar responden dalam Tabel 12 menyatakan bahwa perizinan usaha cukup mudah prosesnya sebanyak $96 \%$. Infrastruktur yang dibangun pemerintah memadai dan membantu jalannya usaha dalam hasil survey sebesar $97 \%$. Menurut $96 \%$ responden sulit untuk mendapatkan pendanaan dengan bunga lunak dari pemerintah, ditambah lagi dengan prosedur yang cukup rumit dan kurangnya kegiatan pembinaan program kemitraan usaha dari pemerintah, serta dirasakan tidak adanya perindungan usaha baik dari monopoli maupun dari ekspansi eksternalitas.

\section{9) Aspek Eksternalitas dan Lain-lain}

Eksternalitas merupakan efek yang dirasakan oleh responden atau pelaku usaha UMKM baik eksternalitas positif maupun eksternalitas negatif.

Tabel 13. Aspek Eksternalitas dan Lain-lain

\begin{tabular}{|c|c|c|}
\hline Aspek Eksternalitas dan Lain-lain & Frekuensi & Persen (\%) \\
\hline $\begin{array}{l}\text { Adanya tingkat gangguan keamanan pada usaha yang tinggi } \\
\text { (pencurian, penipuan, kriminal dll) } \\
\text { Terdapat persainaan vana menahambat usaha terutama dari }\end{array}$ & 25 & 25 \\
\hline produk-produk luar negeri (asing) & 22 & 22 \\
\hline $\begin{array}{l}\text { Ketidak stabilan politik cukup mempengaruhi dan menghambat } \\
\text { perkembangan usaha }\end{array}$ & 4 & 4 \\
\hline $\begin{array}{l}\text { Tingkat inflasi yang tinggi (harga-harga mahal) sangat signifikan } \\
\text { mempengaruhi perkembangan usaha }\end{array}$ & 42 & 42 \\
\hline $\begin{array}{l}\text { Kondisi perekonomian secara umum dirasakan berat dan } \\
\text { mempengaruhi perkembangan usaha }\end{array}$ & 45 & 45 \\
\hline
\end{tabular}

Berdasarkan Tabel 13 aspek eksternalitas dan lainnya menunjukkan tingkat inflasi sedikit banyak memberikan pengaruh pada pertumbuhan ekonomi UMKM kota Tarakan sekitar 45\% responden menyatakan hal tersebut. Namun dari eksternalitas yang terjadi, efek dari eksternalitas positif yang lebih dominan menurut responden karena hanya sebagian kecil dari responden saja yang menyatakan adanya tingkat gangguan pada usaha yang tinggi, persaingan yang dianggap menjadi hambatan dan ketidakstabilan politik mampu memicu dan menghambat perkembangan usaha UMKM di kota Tarakan.

\section{Strategi Meningkatkan Daya Saing pada UMKM di Kota Tarakan}

Membuat perencanaan strategis perlu alat analisis yang tepat, maka digunakan alat analisis SWOT untuk mengidentifikasi berbagai faktor secara sistematis untuk merumuskan strategi pengembangan strategi pengembangan usaha yang efektif untuk meningkatkan daya saing dalam menghadapi kompetitif pasar bebas, pada UMKM di Kota Tarakan. Analisis SWOT adalah adalah metode perencanaan strategis yang berfungsi untuk mengevaluasi kekuatan, kelemahan, peluang, dan ancaman dalam perumusan strategis bagi UMKM kota Tarakan.

Proses ini melibatkan penentuan tujuan yang spesifik dari spekulasi bisnis dan mengidentifikasi faktor internal dan eksternal yang mendukung dan yang tidak dalam mencapai tujuan tersebut. Berikut ini adalah rincian mengenai kekuatan, kelemahan, peluang dan ancaman dalam pengembangan usaha yang efektif untuk meningkatkan daya saing dalam menghadapi kompetitif pasar bebas, pada UMKM di Kota Tarakan. 
1. Faktor Internal yang berasal dari dalam usaha UMKM kota Tarakan yang berupa kekuatan dan kelemahan UMKM Kota Tarakan

a. Kekuatan, terdiri dari :

1) Legalitas produk dan ijin produk diakui oleh umum;

2) Harga produk yang mampu bersaing dari produk-produk sejenis;

3) Bahan baku mudah diperoleh, harga bahan baku murah dan kualitas dari bahan baku konsisten;

4) Ada jenjang peningkatan kualitas tenaga kerja dengan memberikan pelatihan;

5) Melakukan perubahan peralatan yang lebih canggih dan efisien, serta menyediakan peralatan tambahan lainnya sebagai penunjang usaha UMKM.

b. Kelemahan, terdiri dari :

1) Terbatasnya modal yang dimiliki oleh pelaku UMKM;

2) Kurangnya pemahaman dari pelaku UMKM tentang manajemen usaha, strategi, sistem dan proses pemasaran bagi hasil produksinya;

3) Sebagian besar UMKM kota Tarakan belum terdaftar dalam paguyuban/asosiasi usaha yang ada di kota Tarakan;

4) Kurangnya jaringan pemasaran dan teknologi informasi penunjang pengembangan bagi UMKM;

5) Ketersediaan SDM yang memiliki keahlian dan pengalaman yang kurang.

2. Faktor Eksternal yang berasal dari luarusaha UMKM kota Tarakan yang berupa peluang dan ancaman UMKM Kota Tarakan.

a. Peluang, terdiri dari :

1) Memiliki spesialisasi ekspor yang tidak dimiliki oleh Negara-negara tetangga seperti hasil laut;

2) Kecenderungan konsumsi masyarakat yang cukup besar terhadap hasil local;

3) Rendahnya tingkat gangguan keamanan pada usaha UMKM di Kota Tarakan (pencurian, penipuan, kriminal dII);

4) Program pemerintah dalam peningkatan potensi UMKM kota Tarakan sebagai unit usaha yang perlu diperhitungkan;

5) Sistem birokrasi yang mudah dari pemerintah dan ketersedian infrastruktur pendukung.

b. Ancaman, terdiri dari :

1) Kondisi perekonomian secara umum dirasakan berat dan mempengaruhi perkembangan usaha UMKM Kota Tarakan;

2) Tingkat Inflasi yang selalu meningkat dari tahun ke tahun yang sulit untuk diredam;

3) Masih kurangnya perlindungan usaha baik dari monopoli maupun dari ekspansi eksternal dari pemerintah;

4) Sulitnya mendapatkan pendanaan bunga lunak dari pemerintah karena prosedur pendanaan yang tergolong rumit;

5) Adanya hambatan secara eksternal seperti kesediaan tenaga listrik yang dianggap mengganggu kegiatan operasional dari UMKM di kota Tarakan. 
Tabel 14. Analisis SWOT Strategi Pengembangan

\begin{tabular}{|c|c|c|}
\hline $\begin{array}{l}\mathrm{I} \\
\mathrm{N} \\
\mathrm{T} \\
\mathrm{E} \\
\mathrm{R} \\
\mathrm{N} \\
\mathrm{A} \\
\mathrm{L}\end{array}$ & $\begin{array}{l}\text { Kekuatan } \\
\text { 1. Legalitas produk dan ijin produk diakui oleh } \\
\text { umum } \\
\text { 2. Harga produk yang mampu bersaing dari } \\
\text { produk-produk sejenis } \\
\text { 3. Bahan baku mudah diperoleh, harga bahan } \\
\text { baku murah dan kualitas dari bahan baku } \\
\text { konsisten } \\
\text { 4. Ada jenjang peningkatan kualitas tenaga kerja } \\
\text { dengan memberikan pelatihan } \\
\text { 5. Melakukan perubahan peralatan yang lebih } \\
\text { canggih dan efisien, serta menyediakan } \\
\text { peralatan tambahan lainnya sebagai } \\
\text { penunjang usaha UMKM }\end{array}$ & $\begin{array}{l}\text { Kelemahan } \\
\text { 1. Terbatasnya modal yang dimiliki oleh pelaku } \\
\text { UMKM } \\
\text { 2. Kurangnya pemahaman dari pelaku UMKM } \\
\text { tentang manajemen usaha, strategi, sistem } \\
\text { dan proses pemasaran bagi hasil } \\
\text { produksinya. } \\
\text { 3. Sebagian besar UMKM kota Tarakan belum } \\
\text { terdaftar dalam paguyuban/asosiasi usaha } \\
\text { yang ada di kota Tarakan } \\
\text { 4. Kurangnya jaringan pemasaran dan } \\
\text { teknologi informasi penunjang } \\
\text { pengembangan bagi UMKM } \\
\text { 5. Ketersediaan SDM yang memiliki keahlian } \\
\text { dan pengalaman yang kurang }\end{array}$ \\
\hline $\begin{array}{l}\mathrm{E} \\
\mathrm{K} \\
\mathrm{S} \\
\mathrm{T} \\
\mathrm{E} \\
\mathrm{R} \\
\mathrm{N} \\
\mathrm{A} \\
\mathrm{L}\end{array}$ & $\begin{array}{l}\text { Peluang } \\
\text { 1. Memiliki spesialisasi ekspor yang tidak dimiliki } \\
\text { oleh Negara-negara tetangga seperti hasil } \\
\text { laut. } \\
\text { 2. Kecenderungan konsumsi masyarakat yang } \\
\text { cukup besar terhadap hasil lokal. } \\
\text { 3. Rendahnya tingkat gangguan keamanan } \\
\text { pada usaha UMKM di Kota Tarakan } \\
\text { (pencurian, penipuan, kriminal dll) } \\
\text { 4. Program pemerintah dalam peningkatan } \\
\text { potensi UMKM kota Tarakan sebagai unit } \\
\text { usaha yang perlu diperhitungkan. } \\
\text { 5. Sistem birokrasi yang mudah dari pemerintah } \\
\text { dan ketersedian infrastruktur pendukung }\end{array}$ & $\begin{array}{l}\text { Ancaman } \\
\text { 1. Kondisi perekonomian secara umum } \\
\text { dirasakan berat dan mempengaruhi } \\
\text { perkembangan usaha UMKM Kota Tarakan } \\
\text { 2. Tingkat Inflasi yang selalu meningkat dari } \\
\text { tahun ke tahun yang sulit untuk diredam } \\
\text { 3. Masih kurangnya perlindungan usaha baik } \\
\text { dari monopoli maupun dari ekspansi } \\
\text { eksternal dari pemerintah } \\
\text { 4. Sulitnya mendapatkan pendanaan bunga } \\
\text { lunak dari pemerintah karena prosedur } \\
\text { pendanaan yang tergolong rumit. } \\
\text { 5. Adanya hambatan secara eksternal seperti } \\
\text { kesediaan tenaga listrik yang dianggap } \\
\text { mengganggu kegiatan operasional dari } \\
\text { UMKM di kota Tarakan }\end{array}$ \\
\hline
\end{tabular}

Sumber : Data primer diolah, 2016

Tabel 15. Faktor Strategi Internal (IFAS)

\begin{tabular}{lccc}
\hline \multicolumn{1}{c}{ Faktor-faktor Strategis Internal } & Bobot & Rating & Skor \\
\hline $\begin{array}{l}\text { Kekuatan } \\
\text { 1. Legalitas produk dan ijin produk diakui oleh umum }\end{array}$ & 0,15 & 3 & 0,45 \\
2. Harga produk yang mampu bersaing dari produk-produk sejenis & 0,10 & 3 & 0,30 \\
3. Bahan baku mudah diperoleh, harga bahan baku murah dan kualitas \\
$\begin{array}{l}\text { dari bahan baku konsisten } \\
\text { Ada jenjang peningkatan kualitas tenaga kerja dengan memberikan } \\
\begin{array}{l}\text { pelatihan. } \\
\text { Melakukan perubahan peralatan yang lebih canggih dan efisien, serta } \\
\text { menyediakan peralatan tambahan lainnya sebagai penunjang usaha }\end{array}\end{array}$ & 0,15 & 4 & 0,60 \\
$\quad$ UMKM & 0,05 & 3 & 0,15 \\
\hline SUBTOTAL & 0,50 & 2 & 0,10 \\
\hline
\end{tabular}


Tabel 15. Lanjutan

\begin{tabular}{|c|c|c|c|}
\hline \multicolumn{4}{|l|}{$\begin{array}{ll} & \text { Faktor-faktor Strategis Internal } \\
\text { Kelemahan } & \end{array}$} \\
\hline \multicolumn{4}{|l|}{$\begin{array}{l}\text { Kelemahan } \\
\text { 1. Terbatasnya modal vang dimiliki oleh pelaku UMKM }\end{array}$} \\
\hline 1. Terbatasnya modal yang dimiliki oleh pelaku UMKM & 0,05 & 2 & 0,10 \\
\hline $\begin{array}{l}\text { 2. Kurangnya pemahaman dari pelaku UMKM tentang manajemen usaha, } \\
\text { strategi, sistem dan proses pemasaran bagi hasil produksinya. }\end{array}$ & 0,15 & 3 & 0,45 \\
\hline 3. Sebagian besar UMKM kota Tarakan belum terdaftar dalam & & & \\
\hline paguyuban/asosiasi usaha yang ada di kota Tarakan & 0,15 & 4 & 0,60 \\
\hline $\begin{array}{l}\text { 4. Kurangnya jaringan pemasaran dan teknologi informasi penunjang } \\
\text { pengembangan bagi UMKM }\end{array}$ & 0,10 & 3 & 0,30 \\
\hline 5. Ketersediaan SDM yang memiliki keahlian dan pengalaman yang kurang & & & \\
\hline & 0,05 & 2 & 0,10 \\
\hline SUBTOTAL & 0,50 & & 1,55 \\
\hline TOTAL & 1,00 & & 3,15 \\
\hline
\end{tabular}

Sumber : Data primer diolah, 2016

Dari hasil analisis pada Tabel 15 IFAS faktor Stength mempunyai total nilai skor 1,60 sedangkan Weakness mempunyai total nilai skor 1,55. Seperti halnya IFAS, maka pada faktor-faktor strategis eksternal EFAS juga dilakukan identifikasi yang hasilnya ada pada Tabel 16.

Tabel 16. Faktor Strategi Eksternal (EFAS)

\begin{tabular}{|c|c|c|c|}
\hline Faktor-faktor Strategis Internal & Bobot & Rating & Skor \\
\hline \multicolumn{4}{|l|}{ Peluang } \\
\hline i ekspor yang tidak dimiliki oleh Negar & \multirow{2}{*}{0,10} & \multirow[t]{2}{*}{4} & \multirow[t]{2}{*}{0,40} \\
\hline 2. Kecenderungan konsumsi masyarakat yang cukup besar terhadap hasil lokal. & & & \\
\hline $\begin{array}{l}\text { 3. Rendahnya tingkat gangguan keamanan pada usaha UMKM di Kota Tarakan } \\
\text { (pencurian, penipuan, kriminal dII) }\end{array}$ & 0,15 & 3 & 0,45 \\
\hline $\begin{array}{l}\text { 4. Program pemerintah dalam peningkatan potensi UMKM kota Tarakan sebagai } \\
\text { unit usaha yang perlu diperhitungkan. }\end{array}$ & 0,05 & 4 & 0,20 \\
\hline \multirow[t]{2}{*}{ emerintah dan ketersedian infrastr } & 0,15 & 3 & 0,45 \\
\hline & 0,05 & 3 & 0,15 \\
\hline SUBTOTAL & 0,50 & & 1,65 \\
\hline \multicolumn{4}{|l|}{ Ancaman } \\
\hline $\begin{array}{l}\text { 1. Kondisi perekonomian secara umum dirasakan berat dan mempengaruhi } \\
\text { perkembangan usaha UMKM Kota Tarakan }\end{array}$ & 0,07 & 3 & 0,21 \\
\hline \multirow{4}{*}{$\begin{array}{l}\text { 2. Tingkat Inflasi yang selalu meningkat dari tahun ke tahun yang sulit untuk } \\
\text { diredam } \\
\text { 3. Masih kurangnya perlindungan usaha baik dari monopoli maupun dari } \\
\text { ekspansi eksternal dari pemerintah } \\
\text { 4. Sulitnya mendapatkan pendanaan bunga lunak dari pemerintah karena } \\
\text { prosedur pendanaan yang tergolong rumit. } \\
\text { 5. Adanya hambatan secara eksternal seperti kesediaan tenaga listrik yang } \\
\text { dianggap mengganggu kegiatan operasional dari UMKM di kota Tarakan }\end{array}$} & 0,15 & 4 & 0,60 \\
\hline & 0,10 & 3 & 0,30 \\
\hline & 0,12 & 2 & 0,24 \\
\hline & 0,06 & 2 & 0,12 \\
\hline SUBTOTAL & 0,50 & & 1,47 \\
\hline TOTAL & 1,00 & & 3,12 \\
\hline
\end{tabular}

Sumber : Data primer diolah, 2016 
Analisis Tabel 16 menunjukkan bahwa untuk faktor-faktor Opportunity nilai skornya 1,65 dan faktor Threat 1.47. selanjutnya nilai total skor dari masing-masing faktor dapat dirinci, Strength 1,60, Weakness 1,55, Opportunity 1,65 dan Threat 1,47 maka diketahui nilai selisih dari Strength di atas dari nilai Weakness (+) 0,05 dan nilai Opportunity di atas nilai Threat selisih (+) 0,18.

Berdasarkan analisis tersebut di atas menunjukkan bahwa kinerja perusahaan dapat ditentukan oleh kombinasi faktor internal dan eksternal. Kombinasi kedua faktor tersebut ditunjukkan dalam diagram hasil analisis sebagai berikut:

1. Strategi SO (Mendukung Strategi Growth)

Strategi ini dibuat berdasarkan jalan pikiran dari UMKM, yaitu dengan memanfaatkan seluruh kekuatan untuk merebut dan memanfaatkan peluang sebesar-besarnya. Strategi SO yang ditempuh oleh UMKM kota Tarakan, yaitu, Strategi memanfaatkan seluruh kekuatan UMKM yaitu mempertahankan kualitas dari bahan baku, legalitas/ijin produk yang masuk dalam kualifikasi, harga yang tetap bersaing dan melakukan peningkatan SDM di dalam UMKM.

2. Strategi ST (Mendukung Strategi Diversifikasi)

Adalah strategi dalam menggunakan kekuatan yang dimiliki UMKM untuk mengatasi ancaman. Strategi ST ditempuh oleh UMKM kota Tarakan yaitu dengan menggunakan kekuatan akses perolehan bahan baku yang murah dan berkualitas, merubah peralatan produksi dengan peralatan yang canggih dan efisien, melakukan inovasi dan promosi yang lebih kreatif, memperbaiki manajemen dan meningkatkan komunikasi yang baik antara pimpinan dan karyawan.

3. Strategi WO (Mendukung Strategi Turn-Around)

Strategi ini diterapkan berdasarkan pemanfaatan peluang yang ada dengan cara meminimalkan kelemahan yang ada. Strategi WO yang ditempuh UMKM kota Tarakan antara lain:

a. Meningkatkan SDM berpendidikan dan memberi pelatihan bagi karyawan yang sudah ada.

b. Menambah dan memperbaharui sarana prasarana jaringan pemasaran dan teknologi informasi penunjang pengembangan bagi UMKM.

c. Memperbaiki dan meningkatkan manajemen usaha, strategi, sistem dan proses pemasaran bagi hasil produksinya.

d. Meningkatkan modal yang dimiliki oleh pelaku UMKM dengan penggunaan pendanaan dari pemerintah maupun lembaga keuangan.

e. Mendaftarkan UMKM kota Tarakan belum terdaftar dalam paguyuban/asosiasi usaha yang ada di kota Tarakan, agar semakin terbuka akses pemasaran dan jaringan usaha UMKM kota Tarakan.

4. Strategi WT (Mendukung Strategi Defensif).

Strategi ini didasarkan pada kegiatan yang bersifat defensive dan berusaha meminimalkan kelemahan yang ada serta menghindari ancaman. Strategi WT yang ditempuh oleh UMKM kota Tarakan antara lain:

a. Kondisi perekonomian secara umum menjadi dasar perencanaan ke depan bagi perkembangan usaha UMKM Kota Tarakan.

b. Menjaga stabilisasi dari usaha baik dari penggunaan bahan baku, pemasaran, tenaga kerja hingga birokrasi pemerintahan.

c. Mempelajari dan membuat ijin paten guna mendapatkan perlindungan usaha baik dari monopoli maupun dari ekspansi eksternal dari pemerintah.

d. Memperbaiki manajemen internal UMKM agar mudah untuk mendapatkan pendanaan bunga lunak dari pemerintah dengan mempersiapkan prasyarat dari prosedur pendanaan. 
e. Meminimalkan hambatan secara eksternal seperti kesediaan tenaga listrik yang dianggap mengganggu kegiatan operasional dari UMKM di kota Tarakan dengan menyediakan sarana dan prasarana yaitu pelengkap peralatan produksi.

Berdasarkan hasil analisis SWOT strategi pengembangan usaha yang efektif untuk meningkatkan daya saing dalam menghadapi kompetitif pasar bebas, pada UMKM di Kota Tarakan, maka UMKM memiliki kekuatan yang dapat digunakan pada strategi tertentu serta memanfaatkan peluang yang tepat serta secara bersamaan meminimalkan atau menghindari kelemahan dan ancaman yang ada. Posisi ini akan menguntungkan bagi UMKM di kota Tarakan dengan memperbaiki kondisi di atas rata-rata kemampuan sehingga dari UMKM dapat mengendalikan semua faktor internal dan eksternal yang timbul.

\section{PENUTUP}

Berdasarkan analisis internal dan eksternal UMKM kota Tarakan beserta diagram cartesius dapat diperoleh bahwa yang menjadi strategi utama adalah strategi Growth (pertumbuhan) dimana UMKM kota Tarakan memanfaatkan seluruh kekuatan UMKM yaitu mempertahankan kualitas dari bahan baku, legalitas/ijin produk yang masuk dalam kualifikasi, harga yang tetap bersaing dan melakukan peningkatan SDM di dalam UMKM di kota Tarakan.

Permasalahan yang timbul dalam pengembangan usaha pada UMK M di Kota Tarakan dapat diatasi dengan menggunakan Strategi WO dimana strategiini diterapkan berdasarkan pemanfaatan peluang yang ada dengan cara meminimalkan kelemahan yang ada dan strategi WT dengan menitik beratkan pada kondisi perekonomian secara umum menjadi dasar perencanaan ke depan bagi perkembangan usaha UMKM Kota Tarakan.

Bagi UMKM kota Tarakan agar menjaga stabilisasi dari usaha baik dari penggunaan bahan baku, pemasaran, tenaga kerja hingga birokrasi pemerintahan. Mempelajari dan membuat ijin paten guna mendapatkan perlindungan usaha baik dari monopoli maupun dari ekspansi eksternal dari pemerintah memperbaiki manajemen internal meminimalkan hambatan secara eksternal seperti kesediaan tenaga listrik yang dianggap mengganggu kegiatan operasional dari UMKM di kota Tarakan dengan menyediakan sarana dan prasarana yaitu pelengkap peralatan produksi. Bagi pemerintah dan lembaga terkait agar memberikan keleluasaan dalam pengembangan usaha UMKM di kota Tarakan baik dalam hal penyediaan pelatihan, sarana dan prasarana serta penyediaan informasi bagi pengembangan UMKM di kota Tarakan.

\section{REFERENSI}

Chris Manning \& Tadjuddin Noer Effendi. (1991). Urbanisasi, pengangguran dan sektor informal di kota. Yayasan Obor Indonesia, Jakarta.

Hamid Edy Suandi \& Susilo Y. Sri . (2011). Strategi pengembangan usaha mikro kecil dan menengah di provinsi daerah istimewa Yogyakarta. Jurnal ekonomi pembangunan, Vol.12, Nomor 1, Juni 2011, hlm.45-55.

Irdayanti. (2012). Peran pemerintah dalam pengembangan UKM berorientasi ekspor studi kasus: Klaster kasongan dalam rantai nilai tambah global, Jurnal Transnasional, Vol. 3 No. 2 Februari 2012.

Rahmana Arief. (2009). Peranan teknologi informasi dalam peningkatan daya saing usaha kecil menengah, Seminar Nasional, Aplikasi Teknologi Informasi 2009 (SNATI 2009) Yogyakarta.

Rianse Usman, Abdi. (2008). Metodologi Penelitian Sosial dan Ekonomi (Teori dan Aplikasi). Edisi Pertama. Alfabeta, Bandung. 
Sakur. (2011). Kajian faktor-faktor yang mendukung pengembangan usaha mikro kecil dan menengah: Studi kasus di Kota Surakarta. Spirit publik,vol. 7, nomor 2: 85-110 ISSN. 19070489 Oktober 2011.

Sriyana, Jaka. (2010). Strategi Pengembangan Usaha Kecil Dan Menengah (UKM): Studi kasus di Kabupaten Bantul, Simposium nasional 2010: Menuju Purworejo Dinamis dan Kreatif.

Syahza, Almasdi. (2013). Pengembangan Usaha Kecil dan Menengah (UKM) untuk percepatan peningkatan ekonomi daerah di Kabupaten Indragiri Hulu Propinsi Riau, Pusat Pengkajian Koperasi dan Pemberdayaan Ekonomi Masyarakat, Universitas Riau Pekanbaru. 